\title{
Revitalization of Character Development in Civic Education Learning Management
}

\author{
Tjeppy ${ }^{1}$ \\ DOI: 10.35445/alishlah.v13i2.726
}

\begin{abstract}
Article Info
Abstract

Keywords:

Education Management;

Character;

Civic education

This study aims to see the process of reforming education management that impacts students' character development through learning civic education to foster a sense of discipline and defend the country, so that character development is formed. This study uses a descriptive method with a qualitative approach. The data triangulation analysis is strengthened by the literature related to this research. The study results explain that civics learning management improves students' ability to understand various learning methods to be more creative and innovative. Civics lessons play a role in forming student character supported by well-organized education management, improves teachers' performance in delivering civic education subjects, and develop students' ability to instill high national values through civics education.
\end{abstract}

Kata kunci:

Manajemen Pendidikan;

Karakter;

Pendidikan

Kewarganegaraan

\begin{abstract}
Abstrak
Penelitian ini bertujuan untuk melihat proses pembaruan manajemen pendidikan yang memberikan dampak pada pembangunan karakter siswa. Melalui pembelajaran pendidikan kewarganegaraan menumbuhkan rasa sikap displin serta bela negara sehingga terbentuk pembangunan karakter. Penelitian ini menggunakan metode deskriptif dengan pendekatan kualitatif serta analisis triangulasi data dan diperkuat oleh literatur yang berkaitan tentang penelitian ini. Hasil penelitian menjelaskan bahwa manajemen pembelajaran kewarganegaraan adalah sebuah proses dalam meningkatkan kemampuan peserta didik dalam memahami berbagai metode pembelajaran menjadi lebih kreatif dan inovatif. Disamping itu mata pelajaran kewarganegaraan ikut berperan dalam pembentukan karakter siswa yang di dukung dengan sebuah manajemen pendidikan yang telah terorganisasi dengan baik, meningkatkan kinerja para guru dalam menyampaikan mata pelajaran pendidikan kewarganegaraan, dan mengembangkan kemampuan peserta didik dalam menanamkan nilai-nilai kebangsaan yang tinggi melalui sebuah pendidikan kewarganegaraan.
\end{abstract}

\footnotetext{
${ }^{1}$ Universitas Suryakancana, Cianjur, Indonesia

Email: tjeppysulaeman21@gmail.com
} 


\section{INTRODUCTION}

The goal of education is to mold students' personalities with the process serving a noble purpose and task. It is establishing a nation's insight and civilization through character-building education that can help these kids reach their full potential. A human person must be honest, creative, and self-sufficient. They must develop into human beings who are religiously obedient and accountable as just and enlightened citizens. According to Article 3 of Law No. 20 of 2003 Concerning the National Education System, national education serves to develop capabilities and mold the character civilization of a dignified nation in order to educate the country and state's life (Efaningrum, 2008; Widodo \& Setiyawan, 2021).

Creating an education system based on the nation's and state's progress requires a learning process that improves the quality and quality of its students, so a breakthrough in learning models management is required to produce younger generations who are much more disciplined and disciplined. It has a strong character; it is specified in state legislation that education must be used as a weapon by the state to develop dignity and educate the nation; character is the most critical attitude (Simangunsong, 2019; Sari \& Wardani, 2021). It must be possessed by all humans, particularly the younger generation, who will bear a significant duty in upholding the nation's dignity and upholding the excellent name that must always be carried wherever they go. However, all of this must go through a lengthy process to prevent children from developing attitudes that may lead to erroneous associations and are at odds with religious and state values. The character crisis is currently engulfing this country. Some students have promiscuity, which is marked by rampant free sex, drug abuse, and violence against children. This is an irony in itself that has not found the right solution to prevent it (Mustikaningrum et al., 2020; Prasetiyo et al., 2020; Siregar \& Wirasti, 2021). The Indonesian nation appears to be dealing with a character crisis that has affected some of its students, with a rise in promiscuity typified by rampant free sex, drug addiction, and violence towards children, which is an irony in and of itself that has yet to be overcome.

Of course, as a country that consistently upholds Pancasila and the 1945 Constitution, the Indonesian people must continually cultivate the values of disciplined character and responsibility through a structured and equitable education system. It starts from elementary school to university level, to form a more diverse learning method, must begin by creating education itself. Still, a good education must, of course, produce a superior generation capable of realizing all of their potentials. On the other hand, the actual meaning of education is a person's attempt to acquire information as a provision for life to attain a better future. While the character is innate, heart, soul, personality, behavior, personality, nature, character, temperament, and character are all brilliant. According to Zainal and Sujak (2011), the character is the overall temperament and disposition that has been mastered consistently and characterizes an individual in the general code of behavior that makes them typical in thinking and acting. To establish a sound educational system and pattern, management must always provide the best facilities and facilities that can support various conveniences in creating a learning process that is by the criteria that many students desire; this step is considered initial capital in the development of a national education system founded on the values of discipline and accountability.

Learning must begin with small steps that can lead to a larger goal and civilizational values based on the Constitution and Pancasila as the nation's reflection and ideology because an education system with character will produce many superior generations and create ideal conditions for the Indonesians. So if education is linked to forming a nation's character, the educational concept must always aim for everyday life without constantly looking at a difference in a narrower sense. The educational scale must prioritize ethnicity, religion, race, and community values.

Civic education is a topic that covers much ground in terms of how students can learn to understand and explain the varied meanings and values of democracy throughout history. Aside from that, kids are supposed to grow into individuals who constantly follow the rules, even if they are contradictory. Schools are the most trusted institution in developing educational science and 
developing various potentials of students. Schools should always have a duty to provide a service related to character learning methods. Understanding citizenship education help students more familiar with the values of the 1945 Constitution, and Pancasila is the motto of Indonesian citizens. As the most trusted institution in developing educational science and developing various potentials of students, schools should always have a duty to provide a service related to character learning methods. Understanding citizenship education as an effort of good learning management and education management is important because citizenship subjects allow students to demonstrate all of their abilities in mastering the various democratic mechanisms that exist in Indonesia, according to national education experts who believe that increased teacher understanding of character building is necessary. In line with the idea of national education experts who say it is necessary to increase teacher understanding of character building through synergistic activity, In addition, the higher education office, in partnership with the Teacher Working Group (KKG), must include some awareness of the relevance of human rights values in some of the information contained in the civics education learning method. In maximizing a civic education teacher's role in supporting various delivery, the learning process requires a unique method to accelerate the achievement of goals that connect students and teachers. The form must adapt to the conditions and characteristics of children because every child has different conditions and potential, the teacher's role must be more individualized (Suriadi et al., 2021). a country that always prioritizes the nation's democratic values.

The study's goals and objectives are to figure out how to rejuvenate character development in civic education learning management. In building national character, educational institutions should be revitalized. The results of this previous study explained that the revitalization is related to the selectivity of educational institutions in the recruitment of teachers so that the quality standards used in teaching staff recruitment are not low. Arini et al. (2021) used a qualitative descriptive research method to compile this research, and the results of this previous study explained that the revitalization at this point is related to the selectivity of educational institutions in the recruitment of teachers so that the quality standards used in teaching staff recruitment are not low. Character education must be improved and developed correctly and regularly to reach all levels and types of education in Indonesia.

Character Education Learning is being revitalized. Cahyadi (2014) used normative qualitative research methodologies to assemble this study. The findings show that character education is more than just a subject matter related to religion and civic education; it also necessitates several reformative measures across the board. As a result, character education becomes a task that requires knowledge of both the upstream and downstream worlds of education. Character Education Revitalization as a Means of Strengthening National Awareness has been studied by Inmandari et al. (2020). Revealed that the application of character education through classroom learning, socializing, and extracurricular activities constrains a lack of synergy between the values used. Revitalization is continuous and consistent through learning and socialization, and direct practice.

Character education is being implemented through citizenship education subjects. Suardi et al. (2019) used descriptive qualitative research methodologies to assemble this study. The findings revealed that the instructor implemented character education through civic education subjects in three stages. Specifically, the planning, implementation, and assessment stages, as well as some of the impeding factors experienced by teachers in implementing character education, such as students' lack of awareness in following rules, students' loss of motivation in learning, and students' lack of understanding in making school assignments and the efforts made. Teachers do overcome these difficulties by enacting punishments to ensure that all children receive equal attention. Citizenship Revitalization Learning as a means of developing character The Empowerment of School Culture is a method of empowering the culture of a school. The findings of this study have implications that the construction of Civics learning processes that include character formation in children must begin with the creation of varied educational settings. Character-building activities conducive to learning 
are synergistic in various ways, including teacher appreciation, school culture, principal leadership, and learning design.

Difference from previous research, this research focuses on revitalizing character development in Civics learning management. Civics lessons are essential in shaping and fostering the character of students in fostering a sense of nationalism.

\section{METHODS}

The researcher uses a qualitative descriptive approach to examine a phenomenon that discusses revitalizing character development in civic education learning management. The data used in this study comes from two sources: primary data and secondary data. Secondary data refers to the primary data related to the topic and research under consideration. The researcher obtains from journals and other references related to the revitalization of character development through civic education management. There are 15 journal articles used as study material in this study. The article was obtained from journals published from 2017 to 2020 with SINTA 2 accreditation level. The primary goal of using data analysis techniques in qualitative research is to reduce the amount of data and facts that have been encountered in the field to a form that is easier to grasp, or the data is summarised and concluded more easily for interpretation.

The primary goal of using data analysis techniques in the following qualitative research method is to simplify the data and facts gathered in the field into a form that is easier to grasp or summarised and concluded for straightforward interpretation. The fundamental goal of using data analysis techniques at the following step of the qualitative research method is to alleviate the data and facts found in the field in a form that is easier to grasp or summarised and concluded more easily for interpretation.

\section{FINDINGS AND DISCUSSION}

The findings of the research, which was conducted using the observation method on several articles related to the topic of revitalizing character development through civic education management, as well as evaluating and analyzing the data gathered in the field, some conclusions and discussions can be drawn, namely:

\section{Revitalizing Educational Institutions towards Citizenship Character Education}

Educational revitalization is an effort to advance education quality that is growing and developing through a learning method based on civic education subjects. Additionally, this revitalization is expected to shape the characters of far superior students who can contribute more in realizing a national education system based on noble character and high integrity in the values o (Permendiknas No. 22 of 2006). According to Pancasila and the Constitution of 1945, the Citizenship Education Subject focuses on forming citizens who understand and can carry out their rights and obligations to become intellectual, skillful, and characterized Indonesian citizens.

The first step in improving a student's character education system, particularly in schools, is to expand human resources. This process will be mutually sustainable, with civic education subjects for pupils serving as the main item in which all values will be carried out. After everything goes according to plan and a new culture emerges in the learning model, the next step is to assess how far this educational process has progressed so that later. In a learning setting, learning is the process of students interacting with educators and learning resources (Fathoni, 2015).

Students can participate in activities socialization of character education after participating in various civic character education. It had instilled character education in principle long before the country became independent. So, when talking about a revitalization of character education that focuses on the nation's moral education, Civics plays a more significant role in democratic political education than in values and national education.

There are a variety of approach concepts in shaping a character education process. Some of these steps are believed to accelerate the growth rate of students in understanding the revitalization 
of the nation's character education. The first is the value classification approach, followed by the community justice approach, caring approach, and moral character education. Furthermore, the teacher must be able to swiftly adjust to all character education methods, where all of these procedures must be supported by a professional attitude, and everything must be implemented in an educational curriculum and directed to the best possible outcome. Furthermore, the teacher's responsibility is to adjust to all character education methods swiftly. A professional attitude must support these procedures, and everything must be implemented in an educational curriculum and directed to the best possible outcome (Oktaviani, 2020).

Each level of a civic character education implemented through a learning technique must always be carefully analysed, with the learning process being deemed excellent if the student's original character does not alter at all. Despite this, students can thoroughly explain numerous aspects of civic character education. A common opinion between a teacher and students is the most important thing at all stages of character development. Evaluation is the final part of the stage in developing civic character education learning. It includes all series that have been composed of the introduction of learning methods to the stages of application, measurement, and development of the school. The configuration of PKn is created in three systemic frameworks, namely PKn in curricular, theoretical, and practical terms programmatically, and PKn in curricular, theoretical, and practical terms programmatically (Budimansyah, 2006; Kristini, 2021).

Following a review of the rejuvenation of civic education management, it can be determined that the character education learning technique is a very effective method that should be implemented at various levels of education in Indonesia because the country loves its people. Civic education is the foundation for forming generations of noble character and behavior, is emphasized in Law No. 20 of 2003 Article 3 concerning the National Education System, which states that national education develops abilities and shapes the character and civilization of a dignified nation.

\section{Improving Character Development Through Citizenship Education Learning Management}

The development of educational character through civic education empowerment management is an effort that will be realized through a comprehensively structured relationship between human resources and the school environment as a place where character learning activities take place. Essentially the interactions that occur between a teacher and the school environment. National education aims to develop the potential of students until this system runs regularly. It has a very mature readiness to develop various auxiliary management to realize student character based on national civilization's values combined with an attitude that prioritizes the nation's and state's judicial systems (Depdiknas RI, 2003; Siregar et al., 2021).

Another function of civic education management is the existence of a new system. The system serves as a first step toward achieving national ideals based on good learning programs and, of course, constant striving for changes in new and diverse educational patterns, management of education management. With the renewal of the learning system, students are trained to continue developing and constantly adapting to multiple learning models, which will lead them to a new cultural change that is more complex and challenging. According to Fadjar (2005), education is a powerful vehicle for advancing and respecting the nation and state in the association of countries and the international globe. It thus provides a thorough awareness of the value of education for all Indonesians.

A suitable learning method will undoubtedly produce a very maximum achievement. In the process, all stages of the character education process must be built with a noble intention so that in practice. It will not encounter a failure in educational development. As happened in Indonesia in its efforts to improve a maximum education system, our education has experienced many steep paths where there are so many inhibiting factors that occur in various regions in Indonesia, both internal and external factors. So the magnitude of a responsibility that many students carry out must, of 
course, be accompanied by various efforts to realize an education system that is by the wishes of the Indonesian people. The slowness of planting character learning have to overcome by the government. It could be prepared to develop student interest in learning, be careful in formulating learning curricula and continually improve the quality standards of teaching staff. Education is a commitment that involves the most people. The next improvement is to provide an adequate education budget. This seriousness must always be strived for and targeted every year by improving the welfare of education and in conjunction with the management of a properly structured system that will produce students who have character and are supported with positive attitudes. High responsibility in educational science can change the ideals of a noble nation. Lickona, Schaps, and Lewis (in Megawangi, 2004; Prihandini et al., 2020) explains the principles of character education that educators must implement in schools, namely, socializing and developing ethical values that can shape character, describing character comprehensively or thoroughly, including knowledge, feelings, and behavior. Several things could support the development of student character development. It includes kindness, using a holistic, proactive, practical approach to character development by using teachers as role models, school discipline, learning process curriculum, classroom and school management, integration of character material and all aspects of classroom life, and collaboration with parents and the community, creating an atmosphere love in schools and make schools a model of peace and harmony, providing opportunities for students to carry out good deeds, provide a meaningful academic curriculum in support of student character development or competency-based.

In the context of understanding this phenomenon, it is interesting what UNESCO suggested that education must contain three elements, learning to know (learn to know), learn to do (learn to do) and learn to live together (remember to live together). The first and second elements focus more on forming, so human resources have quality knowledge and skills. The third element is more focused on being towards the formation of national character. In other words, generating a high sense of democracy towards an education system is the task of all levels of society. Understanding good ethical ways and always upholding a sense of brotherhood, among others, is the main task of education to provide an understanding through useful knowledge and quality life.

\section{CONCLUSION}

The civic character learning method is a method that combines student character attitudes that are applied through civic education subjects that have been widely applied at various levels of education in Indonesia. Educational values are based on the Constitution as a guideline for the Indonesian state. Civic education learning has a noble goal that provides a good example and role model for young people as the nation's next generation and as captains in realizing national education ideal for all Indonesian people. Hopefully, with this revitalization of character education, the quality of education in Indonesia can run smoothly. By the ideals of the nation, character education is not only about a combination of religious education and civic education, but there are many aspects involved in it, other things involved in the process. The results of this study are expected to be a reference for educators in building good character and educational goals. This study only examines articles published in Indonesian journals. For further research, it is recommended to enrich the literature by reviewing articles in reputable international journals.

\section{REFERENCES}

Annisa, N., Hasibuan, P. H., \& Siregar, E. F. S. (2020). Menyanyikan Lagu Indonesia Raya sebagai bentuk Impelementasi Penguatan Pendidikan Karakter di SDS Asuhan Jaya Kota Medan. Jurnal Benderang, 1(1), 1-5. http://dx.doi.org/10.30596\%2Fejoes.v1i1.4550

Arini, P. D., Matin, M., \& Zulaikha, S. (2021). Curriculum management during the covid-19 emergency. Journal of Education Research and Evaluation, 5(2). doi; http://dx.doi.org/10.23887/jere.v5i2.31593

BSNP. (2010). Laporan BSNP Tahun 2010. Jakarta: Badan Standar Nasional Pendidikan. 
Budimansyah, D. (2006). Pembelajaran Pendidikan Kewarganegaraan Berbasis Portofolio. Jurnal Civics: Media Kajian Kewarganegaraan, 3(1). https://doi.org/10.21831/civics.v3i1.5736

Cahyadi, A. (2014). Menguatkan Indonesia: Revitalisasi pembelajaran pendidikan karakter. Analisis: Jurnal Studi Keislaman, 14(2), 357-374. https://doi.org/10.24042/ajsk.v14i2.695

Cahyono, H. (2015). Pola Pengembangan Pendidikan Karakter Siswa. Jurnal Dimensi Pendidikan dan Pembelajaran, 3(2), 5-12.

Dewi, R. R., Suresman, E., \& Mustikasari, L. (2020). Implementasi Kebijakan Mata Kuliah Pendidikan Kewarganegaraan Sebagai Pendidikan Karakter di Perguruan Tinggi. Jurnal Edueksos (The journal of social and economics education), IX(1), 1-15.

Dhiu, K. D.,\& Bate, N. 2017. Pentingnya Pendidikan Karakter di Perguruan Tinggi: Kajian Teoritis Praktis: 2nd Annual Proceesding STKIP Citra Bakti Bajawa NTT, 172-176.

Dianti, P. (2014). Integrasi Pendidikan Karakter dalam Pembelajaran Pendidikan Kewarganegaraan untuk Mengembangkan Karakter Siswa. JPIS (Jurnal Pendidikan Ilmu Sosial), 23(1), 58-68. https://doi.org/10.17509/jpis.v23i1.2062

Efianingrum, A. (2008). Pendidikan dan Pemajuan Perempuan: Menuju Keadilan Gender. FONDASIA, 1(9). https://doi.org/10.21831/foundasia.v1ig.5867

Ghufron, A. (2010). Integrasi nilai-nilai karakter bangsa pada kegiatan pembelajaran. Jurnal Cakrawala Pendidikan, 1(3).

Hamalik, O. (2009). Perencanaan Pengajaran Berdasarkan Pendekatan Sistem. Jakarta: PT Bumi Aksara.

Hanum, A., \& Meilinda, A. (2019). Studi Karakterisasi Bersahabat/Komunikatif Pada Siswa SMPN 18 Kota Jambi. Jurnal Publikasi Pendidikan, 9(2), 147-151. https://doi.org/10.26858/publikan.vgi2.9016

Haryanto, R. (2019). Tranformasi Pendidikan Abad 21 Melalui Rumah Belajar. [Online]. Tersedia di http://pena.belajar.kemdikbud.go.id/2019/o7/tranformasi-pendidikan-abad-21-melaluirumah-belajar/. Diakses pada 30 Mei 2020.

Hidayah, Y., Ulfah, N., \& Suyitno. (2019). Pendekatan Pembelajaran Mata Kuliah Wajib Umum Pancasila dan Pendidikan Kewarganegaraan di Perguruan Tinggi. Jurnal Pancasila dan Kewarganegaraan, 4(1), 22-33.

Inmandari, F., Yusuf, N., \& Handayani, T. (2020). Revitalisasi Pendidikan Karakter Sebagai Upaya Peneguhan Kesadaran Nasional Pada Siswa SMAN o1 Batu. Jurnal Civic Hukum, 5(1), 1-11. https://doi.org/10.22219/jch.v5i1.9367

Julaiha, S. (2014). Implementasi Pendidikan Karakter DalamPembelajaran. Dinamika Ilmu, 14(2), 226-238.

Juliardi, B. (2015). Implementasi Pendidikan KarakterMelalui Pendidikan Kewarganegaraan. JURNAL BHINNEKA TUNGGAL IKA, 2(2), 119-126.

Karimah, M. (2015). Implementasi Pendidikan Karakter Dalam Pembelajaran Pendidikan Kewarganegaraan Di Madrasah Salafiyah Ibtidaiyah. IJCETS (Indonesian Journal of Curriculum and Educational Technology Studies), 3(1), 49-55.

Kemendikbud. (2016). Konsep dan Pedoman Penguatan Pendidikan Karakter. Jakarta: Kementerian Pendidikan dan Kebudayaan.

Kristini, E. (2021). Penerapan Metode Discovery Learning Dengan Pendekatan Adiksimba Untuk Meningkatkan Ketrampilan Bertanya dan Hasil Belajar Pendidikan Kewarganegaraan. Journal of Education Action Research, 5(3). http://dx.doi.org/10.23887/jear.v5i3.33109

Kurniawan, M. I. (2013). Integrasi Pendidikan Karakter ke dalam Pembelajaran Kewarganegaraan di Sekolah Dasar. Jurnal Pemikiran dan Pengembangan SD, Jilid 1, No. 1, 37-45.

Lickona, T. (2012). Character Matters. Jakarta: PT Bumi Aksara.

Mustikaningrum, G., Pramusinta, L., Buamona, S. A. M. U., Cahyadi, E., \& Istiqomah, W. (2020). Implementasi Pendidikan Karakter Terintegrasi Kurikulum Dan Metode Pembelajaran Pada Masa Pandemi Covid-19. AULADUNA: Jurnal Pendidikan Dasar Islam, 7(2), 154-164. doi; https://doi.org/10.24252/10.24252/auladuna.v7i2a5.2020

Nurdiansyah, E., El Faisal, E., \& Sulkipani, S. (2018). Pengembangan media pembelajaran berbasis PowToon pada perkuliahan Pendidikan Kewarganegaraan. Jurnal Civics: Media Kajian Kewarganegaraan, 15(1), 1-8. https://doi.org/10.21831/jc.v15i1.16875 
Oktaviani, D. (2020). Meningkatkan Hasil Belajar Pendidikan Kewarganegaraan Siswa Smp Melalui Model Pembelajaran Group To Group Exchange. Academy of Education Journal, 11(01), 112. https://doi.org/10.47200/aoej.v11io1.312

Prasetiyo, E., Suyatno, S., \& Baswedan, A. R. (2020). Manajemen Penguatan Pendidikan Karakter Bebasis Siswa Di Sd Muhammadiyah Karangkajen Yogyakarta. Jurnal RASI, 2(1), 1-17.

Prihandini, S. D., Suryono, H., \& Winarno, W. (2020). Pengaruh Model Pembelajaran Kooperatif Tipe Think Pair Share (TPS) Terhadap Intellectual Skills Siswa Kelas Xi Pada Mata Pelajaran Ppkn Di Sma Negeri 1 Sukoharjo. Jurnal PPKn: Penelitian dan Pemikiran Pendidikan Pancasila dan Kewarganegaraan, 8(1), 62-71. https://doi.org/10.2019/jppkn.v8i1.72

Sari, L. D. K., \& Wardani, K. W. (2021). Pengembangan Buku Cerita Bergambar Digital untuk Meningkatkan Karakter Tanggung Jawab Siswa di Sekolah Dasar. Jurnal Basicedu, 5(4), 1968-1977. doi: https://doi.org/10.31004/basicedu.v5i4.1138

Simangunsong, E. (2019). Factors determining the quality management of higher education: A case study at a business school in Indonesia. Jurnal Cakrawala Pendidikan, 38(2), 215-227. doi: https://doi.org/10.21831/cp.v38i2.19685

Siregar, E., \& Wirasti, R. M. K. (2021). Character education learning for high school students with a Contextual Teaching Learning (CTL) Approach in Civics Subjects in West Seram District. Journal of Education Research and Evaluation, 5(2). doi: http://dx.doi.org/10.23887/jere.v5i2.31760

Siregar, E., \& Wirasti, R. M. K. (2021). Character education learning for high school students with a Contextual Teaching Learning (CTL) Approach in Civics Subjects in West Seram District. Journal of Education Research and Evaluation, 5(2). http://dx.doi.org/10.23887/jere.v5i2.31760

Suardi, S., Herdiansyah, H., Ramlan, H., \& Mutiara, I. A. (2019). Implementasi Pendidikan Karakter Melalui Mata Pelajaran Pendidikan Kewarganegaraan di SMA Jaya Negara Makassar. JED (Journal of Etika Demokrasi), 4(1), 22-29.

Suriadi, H. J., Firman, F., \& Ahmad, R. (2021). Analisis Problema Pembelajaran Daring Terhadap Pendidikan Karakter Peserta Didik. Edukatif: Jurnal Ilmu Pendidikan, 3(1), 165-173. doi: https://doi.org/10.31004/edukatif.v3i1.251

Widodo, S. A., \& Setiyawan, A. (2021). Reforming Understanding About Arabic Curriculum Management: Concept, Characteristics, and Study Area. LISANIA: Journal of Arabic Education and Literature, 5(1), 53-70. doi; https://doi.org/10.18326/lisania.v5i1.53-70

Winataputra, U. S. (2014). Diskursus aktual tentang paradigma pendidikan kewarganegaraan (Pkn) dalam konteks Kurikulum 2013. Bahan Diskusi dalam Semnas PKn-AP3KnI. 